\title{
Ca Channels Induced in Xenopus Oocytes by Rat Brain mRNA
}

\author{
John P. Leonard, Joël Nargeot, ${ }^{a}$ Terry P. Snutch, Norman Davidson, and Henry A. Lester \\ Divisions of Biology and Chemistry, California Institute of Technology, Pasadena, California 91125
}

RNA was isolated from brains of 16-d-old rats and poly(A) samples were injected into stage $V$ and $V I$ oocytes. After allowing 2-5 d for expression, most oocytes were exposed to medium in which the $K$ had been replaced by $C$ s for 24 hr prior to recording. Ba currents were usually measured in Cl-free Ba-methanesulfonate saline.

$I_{B a}$ in noninjected oocytes was often undetectable, but ranged up to $50 \mathrm{nA}(22 \pm 4 \mathrm{nA}, n=21)$. In contrast, injected oocytes showed a peak $\mathrm{I}_{\mathrm{Ba}}$ of $339 \pm 42 \mathrm{nA}(n=33)$. The threshold for activation of $\mathrm{I}_{\mathrm{Ba}}$ was $-\mathbf{4 0} \mathrm{mV}$, with peak currents at +10 to $+\mathbf{2 0} \mathrm{mV}$. After a peak, currents decayed to a nearly steady level along a single-exponential time course $(\tau=650 \pm 50 \mathrm{msec}$ at $+20 \mathrm{mV}$ ). The maintained current was $67 \pm 6 \%(n=9)$ of the early peak amplitude. A prepulse duration of 5 sec was needed to examine the inactivation of barium currents in injected oocytes. The inward $\mathrm{I}_{\mathrm{Ba}}$ could be observed in $\mathrm{BaCl}_{2}$ solutions at potentials positive to $\mathrm{E}_{\mathrm{Cl}}$ and also in Na-free salines, indicating that neither $\mathrm{Cl}^{-}$nor $\mathrm{Na}^{+}$was carrying the inward current.

Although $\mathrm{I}_{\mathrm{Ba}}$ displayed voltage-independent blockade by $\mathrm{Cd}(50 \%$ inhibition at $6 \mu \mathrm{M})$, the peptide $\mathrm{Ca}$ channel antagonist, $\omega$-CgTX (1 $\mu \mathrm{M})$, and the organic $\mathrm{Ca}$ channel-blocking agents (verapamil, compound $W-7$, and nifedipine) were uniformly ineffective. No effects were observed with the dihydropyridine antagonist nifedipine (even at $10 \mu \mathrm{M}$, or when cells were held at $-\mathbf{4 0} \mathrm{mV}$ ) or agonist Bay K-8644. However, $\mathrm{I}_{\mathrm{Ba}}$ was enhanced via activation of protein kinase $C$ with 4- $\beta$ phorbol dibutyrate $\left(\mathrm{PBT}_{2}\right)$. In contrast, use of forskolin to activate protein kinase $A$ did not alter $I_{B_{2}}$. However, experiments in the presence of $\mathrm{Cd}$ revealed that forskolin decreased $I_{k}$. Ca channels produced by rat brain mRNA were thus in contrast to the nifedipine-sensitive, Bay K-8644- and torskolin-enhanced $\mathrm{Ca}$ channels observed after injection of rat heart mRNA (Dascal et al., 1986).

Voltage-dependent calcium channels occur in most neurons and in several other cell types. Clearly, these channels form a diverse group (Carbone and Lux, 1984a, b; Armstrong and Matteson, 1985; Nowycky et al., 1985). Questions that have yet to be answered concern the detailed variation in $\mathrm{Ca}$ channel char-

\footnotetext{
Received June 20, 1986; accepted Sept. 13, 1986.

We thank N. Dascal, D. S. Krafte, and R. J. Miller for helpful suggestions. This research was supported by fellowships from the American Heart Association Greater Los Angeles Affiliate (to J.L. and T.S.), the Conseil de recherches en sciences naturelles et en genie du Canada (to T.S.), and the National Institutes of Health (Grants GM-10991 and GM-29836).

Correspondence should be addresed to John P. Leonard, Division of Biology, 156-29, California Institute of Technology, Pasadena, CA 91125.

a Present address: Laboratoire d'Electrophysiologie et de Pharmacologie Cellulaires, Université F. Rabelais, 37200 Tours; and Centre de Recherches de Biochimie macromoléculaire, CNRS LP 8402, route de Mende 34033, Montepellier, France.

Copyright (C) 1987 Society for Neuroscience $0270-6474 / 87 / 030875-07 \$ 02.00 / 0$
}

acteristics between cell types, the evolutionary relations among them, and the relationship between their structure and function. As one approach to answering these questions, we have begun to apply the technique of expressing genes for $\mathrm{Ca}$ channels in foreign cells. Barnard, Miledi, and their colleagues have demonstrated the expression of various ion channels by mRNA injection in Xenopus oocytes (Gundersen et al., 1983; Houamed et al., 1984); we have shown that voltage-dependent Ca channels can be studied in this way as well (Dascal et al., 1986).

With few exceptions, exogenous mRNA is translated in Xenopus oocytes so as to produce proteins that retain the properties of the donor tissue. Posttranslational modifications, assembly, secretion, sorting, and other processes proceed appropriately (for a review, see Soreq, 1985). For membrane channels, these similarities extend to pharmacology, kinetics, single-channel conductance, and several other characteristics (Dascal, 1987). One may therefore hope to proceed with a characterization of $\mathrm{Ca}$ channel classes based on electrophysiological measurements after injection of RNA from various tissues into Xenopus oocytes. The oocyte system may ultimately allow access to prcsynaptic $\mathrm{Ca}$ channels that are difficult to study in the intact tissue.

The present experiments examine the $\mathrm{Ca}$ channels induced by the injection of mRNA isolated from total rat brain into Xenopus oocytes. We find that robust Ca channel currents (actually carried by $\mathrm{Ba}$ for the usual technical reasons) are induced by rat brain mRNA. Their characteristics differ from those, previously described, induced by injection of mRNA from rat heart. We find major differences that reinforce present concepts about the diversity of $\mathrm{Ca}$ channels.

\section{Materials and Methods}

RNA was isolated from fresh brains of 16-d-old rats by a lithium chloride-urea procedure (Dierks et al., 1981) or by a modification of the guanidine hydrochloride method of Chirgwin et al. (1979). The poly(A) mRNA was isolated from total RNA by chromatography on oligo (dT) cellulose type III (Collaborative Research) by the standard binding and elution protocol of Maniatis et al. (1982). A greater yield of high-molecular-weight RNA was obtained by pretreating the column with a poly $(A)^{-}$fraction from a previous run at roughly $1 \mathrm{mg} / \mathrm{ml}$ in binding buffer, followed by an elution buffer wash. The columns were stored in $0.02 \%$ sodium azide and never rewashed with $\mathrm{NaOH}$.

Adult female $X$. laevis were anesthetized in $0.17 \%$ MS-222 (tricaine methanesulfonate) prior to surgery. Following surgical removal from the frog, oocytes were cleaned of overlying follicle cells by agitation for $3 \mathrm{hr}$ in $2 \mathrm{mg} / \mathrm{ml}$ collagenase (Sigma; Type 1A) in Ca-free saline of the following composition (in millimolar concentrations): $\mathrm{NaCl}, 82.5 ; \mathrm{KCl}$, $2.0 ; \mathrm{MgCl}_{2}, 1.0 ;$ HEPES, 5.0 (titrated to $\mathrm{pH} 7.4$ ). After washing, stage $\mathrm{V}$ and VI oocytes were injected, using a method similar to that of Contreras et al. (1981), with $70 \mathrm{ng}$ samples of poly(A) RNA from rat brains. Noninjected oocytes served as controls. Oocytes were incubated for 3-6 d at room temperature $\left(20^{\circ} \mathrm{C}\right)$ in saline of the following composition: $\mathrm{NaCl}, 96.0 \mathrm{mM} ; \mathrm{KCl}, 2.0 \mathrm{~mm} ; \mathrm{CaCl}_{2}, 1.8 \mathrm{~mm} ; \mathrm{MgCl}_{2}, 1.0 \mathrm{~mm}$; HEPES, $5.0 \mathrm{~mm}$; pyruvate, $2.5 \mathrm{~mm}$; theophylline, $0.5 \mathrm{~mm}$; penicillin, $100 \mathrm{U} / \mathrm{ml}$; streptomycin, $100 \mu \mathrm{g} / \mathrm{ml}$ (titrated to $\mathrm{pH}$ 7.4). In order to 

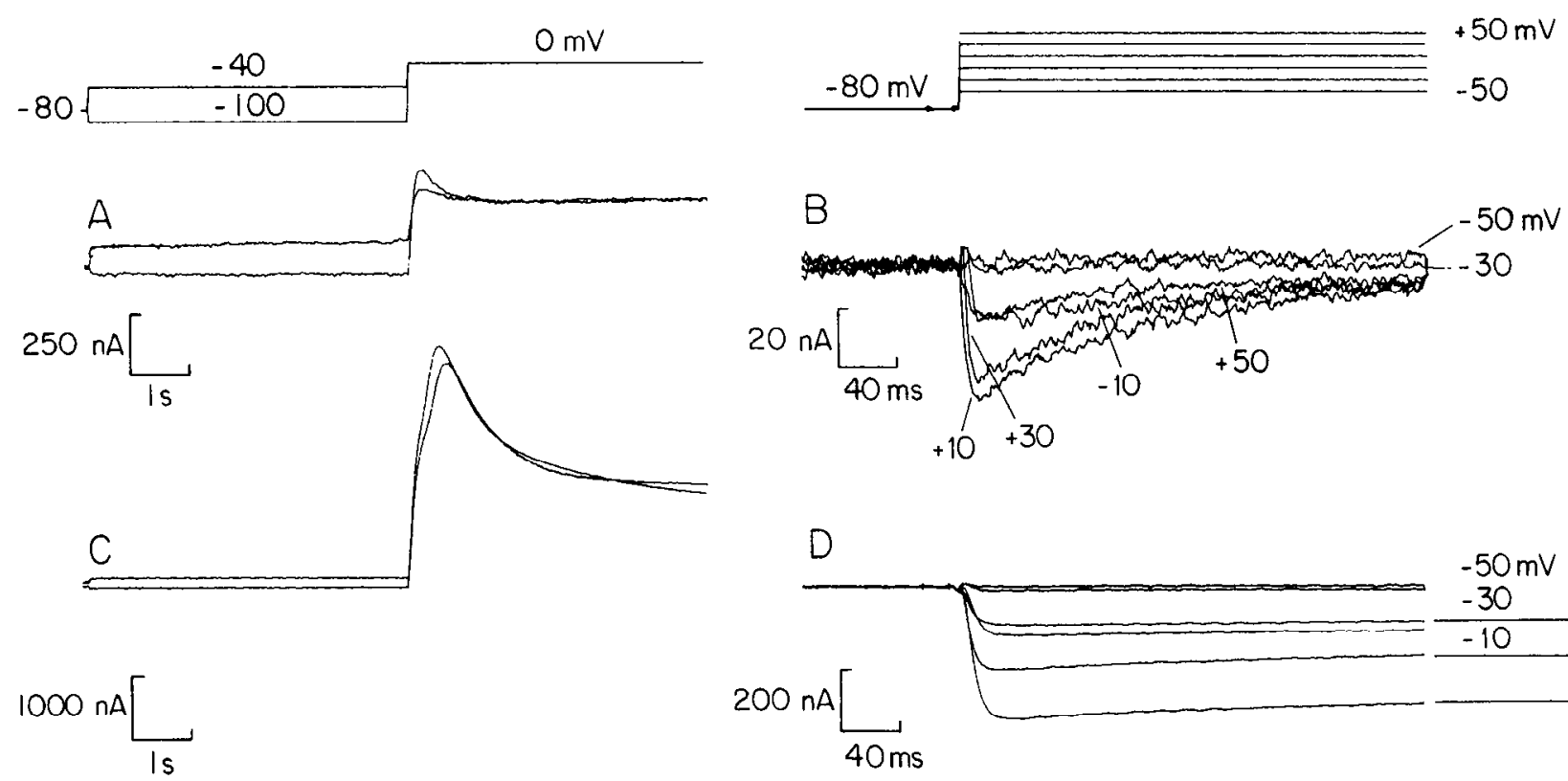

Figure 1. A comparison $\mathrm{ICl}_{\mathrm{Ca}}($ left $)$ and $\mathrm{I}_{\mathrm{Ba}}$ (right) from a noninjected $(A, B)$ and an $\mathrm{mRNA}$-injected $(C, D)$ oocyte. $\mathrm{ICl}_{\mathrm{Ca}}$ elicited by depolarization to $0 \mathrm{mV}$ from a holding potential of -100 or $-40 \mathrm{mV}$ in normal saline was larger for mRNA-injected oocytes $(C)$, and was less inactivated by holding at $-40 \mathrm{mV}$, than $\mathrm{ICl}_{\mathrm{Ca}}$ from noninjected oocytes $(A)$. $\mathrm{I}_{\mathrm{Ba}}$ in BaMS saline was isolated by subtraction of Cd-insensitive currents (see Fig. 2). $I_{\mathrm{Ba}}$ was considerably larger in mRNA-injected oocytes $(D)$ than in noninjected cells $(B)$. Note the relatively rapid decay of $I_{B a}$ in noninjected oocytes. Also note differences in calibration bars for each panel.

reduce $\mathrm{K}$ conductance to facilitate measurement of $I_{\mathrm{Ba}}$, some oocytes were exposed to medium in which the $\mathrm{K}$ had been replaced by $\mathrm{Cs}$ for at least $24 \mathrm{hr}$ before voltage-clamping.

Oocytes were voltage-clamped using a standard 2-intracellular microelectrode circuit. Microelectrodes were filled with $3 \mathrm{M} \mathrm{KCl}$ and had resistances from 0.5 to $2.0 \mathrm{M} \Omega$. Resting potential and $\mathrm{Ca}$-dependent $\mathrm{Cl}$ current were measured in saline of the same ionic composition as the standard incubation medium, but in the absence of pyruvate, theophylline, and antibiotics. $\mathrm{Ba}$ currents were measured in $\mathrm{BaCl}_{2}$ or, more usually, $\mathrm{Cl}$-free $\mathrm{Ba}$-methanesulfonate (BaMS) saline of the following composition (millimolar): $\mathrm{Ba}(\mathrm{OH})_{2}, 40 ; \mathrm{NaOH}, 50 ; \mathrm{KOH}, 2$; HEPES, 5 (titrated to $\mathrm{pH} 7.4$ with methanesulfonic acid). Na-free BaMS saline used in some experiments contained $N$-methyl-D-glucamine as an $\mathrm{Na}$ replacement. All Ba currents were measured in the presence of $1 \mu \mathrm{M}$ TTX. All drugs used were obtained from Sigma, with the exception of omega conotoxin GVIA ( $\omega$-CgTX; gift of Dr. B. M. Olivera), oleoylacetylglycerol (OAG; Calbiochem) and Bay K-8644 (Bayer).

\section{Results}

Noninjected control oocytes in normal saline showed a slow, transient, outward current when depolarized to $0 \mathrm{mV}$ from a conditioning voltage of -40 or $-100 \mathrm{mV}$ (Fig. $1 \mathrm{~A}$ ). This current was due to activation of a Ca-dependent $\mathrm{Cl}$ conductance $\left(\mathrm{gCl}_{\mathrm{Ca}}\right)$ by the influx of $\mathrm{Ca}$ through voltage-dependent $\mathrm{Ca}$ channels in the plasma membrane (Miledi, 1982; Barish, 1983). This $\mathrm{Cl}$ current was relatively small in noninjected oocytes $(\bar{X}=88 \pm$ $22 \mathrm{nA} ; n=22$ ) and was inactivated by a depolarized holding potential; it was only $20 \pm 6 \mathrm{nA}$ when elicited from a holding potential of $-40 \mathrm{mV}$. However, the inward Ca current underlying the $\mathrm{gCl}_{\mathrm{Ca}}$ was difficult to detcet directly because it was masked by the outward $\mathrm{Cl}$ current. As described earlier (Dascal et al., 1986), we used $40 \mathrm{~mm}$ BaMS saline to reveal the small inward current (Fig. $1 B$ ) because Ba often permeates Ca channels better than $\mathrm{Ca}$ does, and also fails to activate $\mathrm{gCl}_{\mathrm{Ca}}$ in oocytes (Barish, 1983). The peak Ba current varied from $<10 \mathrm{nA}$ (7 cases) to as much as $50 \mathrm{nA}(\bar{X}=22 \pm 4 \mathrm{nA} ; n=21)$. The current was transient, with an exponential decay-time constant of roughly $100 \mathrm{msec}$.
In contrast to noninjected cells, oocytes injected with poly(A) RNA from rat brains showed large $\mathrm{ICl}_{\mathrm{Ca}}$ currents both from conditioning voltages of $-40 \mathrm{mV}(1285 \pm 117 \mathrm{nA} ; n=26)$ and from $-100 \mathrm{mV}(1596 \pm 140 \mathrm{nA} ; n=26)$ in normal saline (Fig. 1C). Ba currents recorded in Cl-free BaMS were also much larger (339 $\pm 42 \mathrm{nA} ; n=33$ )-roughly 15 times the control amplitude (Fig. $1 D$ ). All injected oocytes that had $\mathrm{Ca}$-dependent $\mathrm{Cl}$ conductances $>1000 \mathrm{nA}$ in normal saline revealed peak Ba currents $>150 \mathrm{nA}$ when the bath was changed to BaMS saline. Peak $\mathrm{I}_{\mathrm{Ba}}$ elicited after a $5 \mathrm{sec}$ conditioning prepulse at $-40 \mathrm{mV}$ was $76 \pm$ $2 \%$ of the maximal current $(n=6)$. Thus, both brain RNAdirected $\mathrm{ICl}_{\mathrm{Ca}}$ and $\mathrm{I}_{\mathrm{Ba}}$ showed less inactivation than the corresponding endogenous currents.

To obtain a more quantitative estimate of the Ba current through $\mathrm{Ca}$ channels, the inward $\mathrm{Ba}$ current in $\mathrm{Cl}$-free saline was isolated from contaminating outward $\mathrm{K}$ currents by subtracting currents recorded in the presence of $\mathrm{Cd}$ from prior records of total current. In order to further reduce $I_{K}$, most oocytes were exposed to incubation medium in which the $\mathrm{K}$ had been replaced by $\mathrm{Cs}$ for $24 \mathrm{hr}$ prior to electrophysiology. This procedure reduced $I_{K}$, measured as the outward current at $+50 \mathrm{mV}$ in the presence of $\mathrm{Cd}$, by about $70 \%$. Injected oocytes pretreated with $\mathrm{Cs}$ had resting potentials that were, on average, $13 \mathrm{mV}$ more negative than untreated oocytes when recorded in normal (i.e., K-containing) saline. This hyperpolarization began within a few seconds of changing the bath from $\mathrm{K}$-free to normal saline and stabilized in $1 \mathrm{~min}$. The hyperpolarization could be reversed in a few minutes with $1 \mu \mathrm{M}$ strophanthidin, a Na-Kpump blocker. While Cs pretreatment did not completely eliminate $I_{K}$, it did help isolate $I_{B a}$.

Figure 2 shows currents recorded before $(A)$ and after $(B)$ the addition of $100 \mu \mathrm{M} \mathrm{Cd}$ to the bath for a Cs-pretreated cell. The large inward $\mathrm{I}_{\mathrm{Ba}}$ seen in Figure $2 A$ is blocked, and the outward $\mathrm{K}$ current is revealed (Fig. $2 B$ ). Figure $2 C$ shows the subtraction 

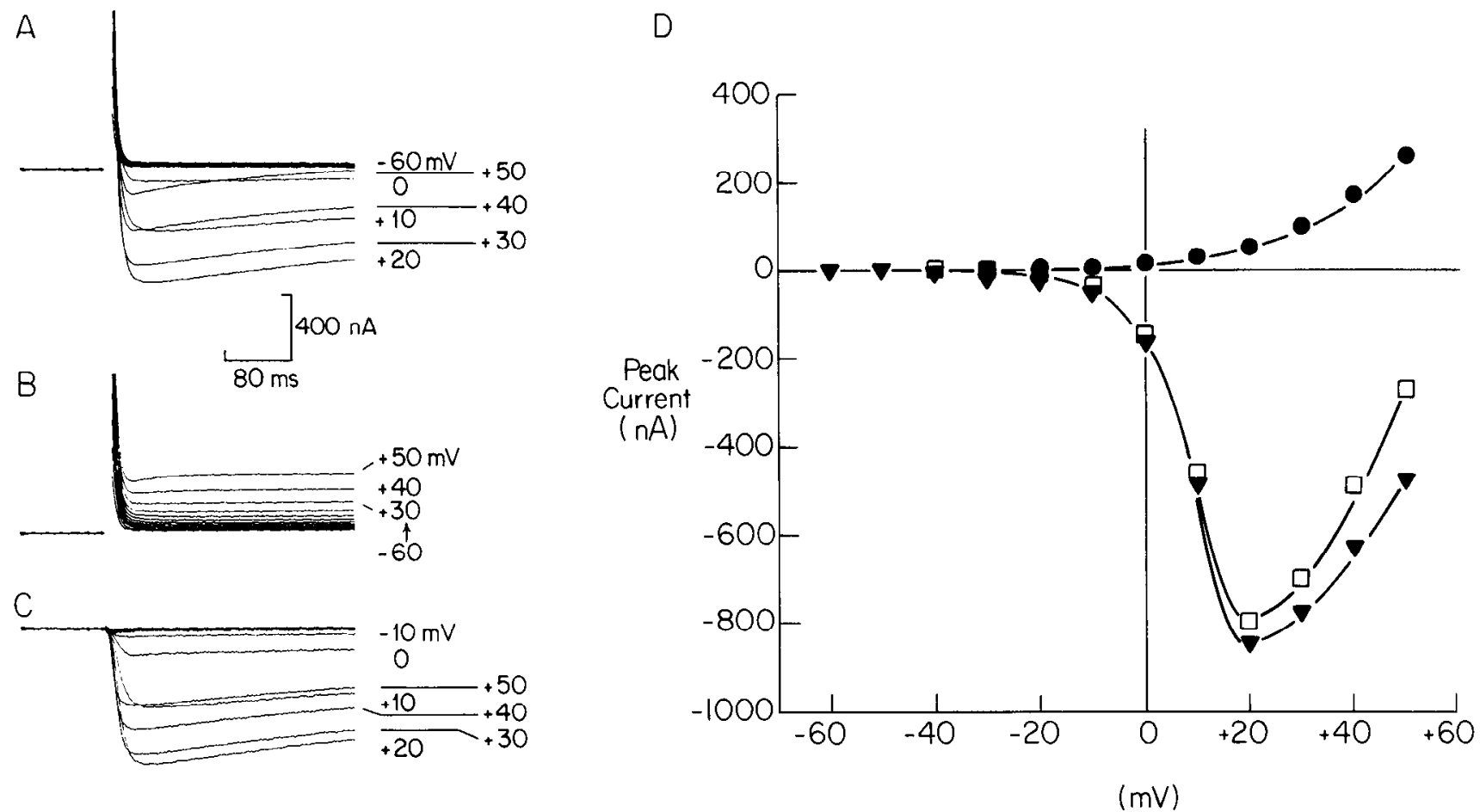

Figure 2. Subtraction of Cd-insensitive currents. $A$, Total currents elicted by depolarizing voltage steps, from a holding potential of $-80 \mathrm{mV}$ to voltages from -60 to $+50 \mathrm{mV}$. $B$, The same voltage protocol in the presence of $100 \mu \mathrm{M}$ Cd reveals Cd-insensitive outward currents carried by potassium. Subtraction of traces in $B$ from total current in $A$ yields the purely Cd-sensitive $\mathrm{I}_{\mathrm{Ba}}$ shown in $C$. Apparent rapid inactivation of current at +40 and $+50 \mathrm{mV}$ was due to activation of $\mathrm{I}_{\mathrm{K}}$. Current-voltage relationships for each family of traces $(A-C)$ are plotted in $D$. Open squares, total current (leak subtracted); filled squares, Cd-insensitive outward current (leak subtracted); triangles, Cd-sensitive $\mathrm{I}_{\mathrm{Ba}}$ (data of panel $C$ ).

of the Cd-insensitive currents of Figure $2 B$ from total current traces in Figure $2 A$. This subtraction seems to reveal a nearly pure $\mathrm{I}_{\mathrm{Ba}}$, and suggests that the apparently more rapid inactivation of total currents elicited by depolarization to +40 and +50 $\mathrm{mV}$ is due to activation of $\mathrm{I}_{\mathrm{K}}$. The current-voltage relationships for each of the families of traces in Figure 2, $A-C$ are shown in Figure $2 D$. The I-V curves for total current and for total current minus Cd-insensitive currents are similar, but diverge at $\mathrm{V}_{\mathrm{m}}>$ $+20 \mathrm{mV}$, where $I_{K}$ is activated. $I_{K}$ is only $5 \%$ of the total current at $+20 \mathrm{mV}$, because peak $I_{\mathrm{Ba}}(\mathrm{at}+20 \mathrm{mV})$ was $850 \mathrm{nA}$ in this cell. Unless otherwise noted, Ba current measurements refer to Cd subtracted traces. The threshold for activation of $I_{\mathrm{Ba}}$ was $-40 \mathrm{mV}$, with peak currents elicited at +10 to $+20 \mathrm{mV}$ in different cells.

Figure 2 also shows that $I_{\mathrm{Ba}}$ undergoes relatively little inactivation during a $300 \mathrm{msec}$ depolarization. Figure $3 A$ shows currents produced by much longer test pulses, from -60 to +50 $\mathrm{mV}$. In experiments like that of Figure 3 , more than $\sim 80 \%$ of the inactivation time course can be described by a single exponential with a time constant of $655 \pm 53 \mathrm{msec}$ ( $n=9$ cells). There is also a component that decays very slowly during a 3 sec depolarization. This current remaining after $3 \mathrm{sec}$ is $67 \pm$ $6 \%(n=9)$ of the early peak amplitude. When a 5 sec conditioning prepulse to $-20 \mathrm{mV}$ was given before depolarization to $+10 \mathrm{mV}$ (Fig. $3 B$ ), peak current was inhibited more than $50 \%$. All oocytes subjected to this pulse protocol showed less than $50 \%$ inactivation of $I_{\mathrm{Ba}}$ at voltages more negative than $-20 \mathrm{mV}$.

$\mathrm{Cl}$-free $\mathrm{BaMS}$ saline, rather than $\mathrm{BaCl}_{2}$ saline, was used for most experiments because, in addition to the $I_{K}$ normally seen in BaMS saline, $\mathrm{I}_{\mathrm{Ba}}$ in $\mathrm{BaCl}_{2}$ saline was often followed by a different outward current. This current may have been dependent on the $\mathrm{Ba}$ influx because it was absent in $100 \mu \mathrm{M} \mathrm{Cd}$. Perhaps a large $\mathrm{I}_{\mathrm{Ba}}$ can release $\mathrm{Ca}$ from intracellular stores and thereby induce $\mathrm{ICl}_{\mathrm{Ca}}$ in $\mathrm{BaCl}_{2}$ but not in BaMS saline. In any case, an inward current in Cl-free BaMS saline could be due to an efflux of intracellular $\mathrm{Cl}^{-}$. This possibility can be rejected because similar large inward $\mathrm{Ba}$ currents can be recorded in $\mathrm{BaCl}_{2}$ saline (Fig. 4), where $\mathrm{Cl}$ current would have been outward at potentials more positive than $\mathrm{E}_{\mathrm{Cl}}(-25 \mathrm{mV})$.

In addition to $\mathrm{Ba}, \mathrm{Na}$ could conceivably carry inward current in BaMS saline. Although all experiments were performed in the presence of $1 \mu \mathrm{M}$ TTX, which completely blocks the voltagedependent Na current produced by injection of rat brain mRNA (Gundersen et al., 1983a), other Na currents can be produced in oocytes under certain circumstances. For instance, prolonged depolarization induces a maintained $\mathrm{Na}$ current in noninjected oocytes (Baud et al., 1982). However, Na does not carry a noticeable inward current under our conditions, since use of Nafree ( $N$-methyl-D-glucamine-replaced) and $\mathrm{Cl}$-free $\mathrm{Ba}$ saline produced very typical inward currents ( $n=5$ cells).

The conclusion that the inward current in BaMS was $\mathrm{I}_{\mathrm{Ba}}$ through $\mathrm{Ca}$ channels is further supported by the high sensitivity to blockade by $\mathrm{Cd}$ (Fig. 5 ). $\mathrm{Cd}$ at $10 \mu \mathrm{M}$ blocked $>50 \%$ of the net inward current; blockade was essentially complete at $500 \mu \mathrm{M}$. Use of $\mathrm{Cd}$ at concentrations $>100 \mu \mathrm{M}$ sometimes caused a dramatic increase in leak current. Another inorganic $\mathrm{Ca}$ channel inhibitor, $\mathrm{Ni}$, was effective only at higher concentrations. An analysis similar to that of Figure 5 showed an apparent dissociation constant for $\mathrm{Ni}$ of $500 \mu \mathrm{M}$. The organic Ca-channel blocker verapamil $(10 \mu \mathrm{M})$ was ineffective in blocking $\mathrm{I}_{\mathrm{Ba}}(n=3$ cells $)$. An 
A

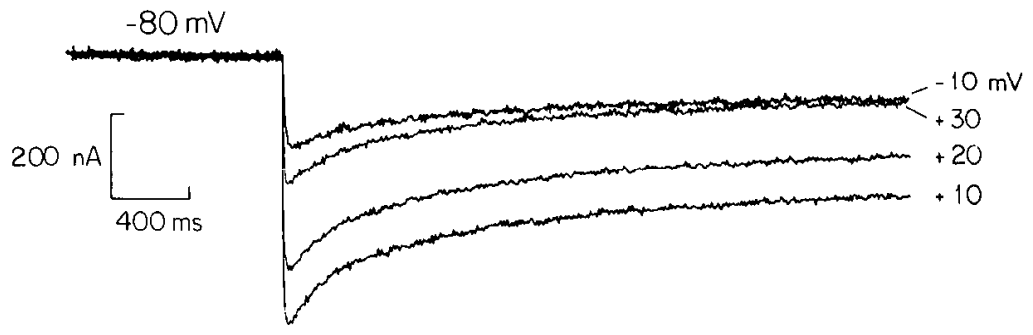

Figure 3. Inactivation of $\mathrm{I}_{\mathrm{Ba}} \cdot A$, Three second depolarizing steps from $-80 \mathrm{mV}$ to indicated voltages revealed slow inactivation of $I_{B a}$ to a nearly steady plateau. $B$. Five second conditioning prepulses before a standard test pulse (to $+10 \mathrm{mV}$ ) showed $>50 \%$ inactivation of peak $I_{\mathrm{Ba}}$ for prepulses $>-20 \mathrm{mV}$. Inactivation was incomplete even for prepulses to $+20 \mathrm{mV}$. Cd-insensitive currents were subtracted out for both $A$ and $B$.

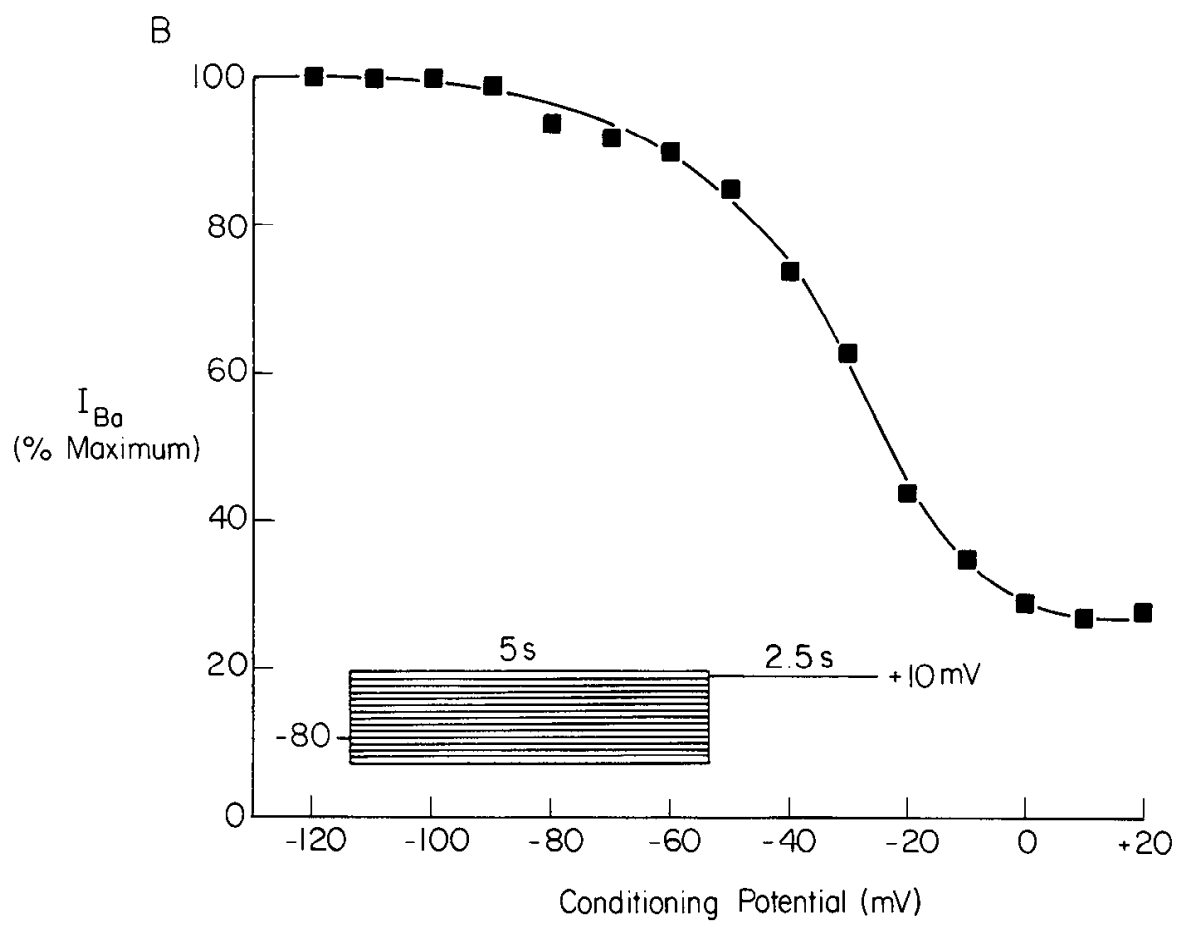

agent that blocks Paramecium calcium channels, $N$ - $(6$ aminohexyl)-5-chloro-1-naphthalenesulfonamide (compound W-7 at $100 \mu \mathrm{M})$, was also ineffective ( $n=4$ cells). Nifedipine at $10 \mu \mathrm{M}$ ( $n=8$ cells) had no effect, even when cells were held at depolarized voltages $(-40 \mathrm{mV})$ to allow $\mathrm{Ca}$ channels to enter a higheraffinity inactivated state (Bean, 1984; Sanguinetti and Kass, 1984). The dihydropyridine $\mathrm{Ca}$ agonist Bay $\mathrm{K}-8644$ also failed to affect $\mathrm{I}_{\mathrm{Ba}}\left(n=3\right.$ cells), although $\mathrm{I}_{\mathrm{Ba}}$ induced by mRNA from rat heart was enhanced by Bay K-8644 ( $n=2$ cells). The peptide calcium channel inhibitor from the marine snail Conus geographus, $\omega$-CgTX, was also ineffective. At $1 \mu \mathrm{M}, \mu$-CgTX failed to alter $\mathrm{I}_{\mathrm{Ba}}$ in BaMS saline or $\mathrm{ICl}_{\mathrm{Ca}}$ in normal saline even after 30 $\min$.

Ba currents were strikingly enhanced by $\mathrm{PBT}_{2}$ (Fig. 6), presumably via activation of protein kinase $\mathrm{C}$. Five to $10 \mathrm{~min}$ after adding $\mathrm{PBT}_{2}$ to the bath (Fig. $6 A$ ), $\mathrm{I}_{\mathrm{Ba}}$ was enhanced $42 \pm 5 \%$ $(n=11)$. The effect was independent of dose over the range of $100 \mathrm{nM}$ to $1 \mu \mathrm{M}$. Control experiments were performed using the parent stereoisomer 4- $\alpha$-phorbol. Slight decreases in peak Ba current $(8 \pm 3 \% ; n=4)$ were found after application of $1 \mu \mathrm{M}$ $4-\alpha$-phorbol $\mathrm{PBT}_{2}$. The increase in inward current due to $\mathrm{PBT}_{2}$ followed the I-V curve for Ba current (Fig. 6B), suggesting that enhanced Ca-channel activity was responsible. Phorbol esters produced no major changes in the waveform or voltage sensitivity of $I_{B a}$. The effect of $\mathrm{PBT}_{2}$ was smaller in Na-free saline $(10 \pm 6 \% ; n=3)$. Although $\mathrm{I}_{\mathrm{K}}$ is relatively small at voltages that elicit peak $I_{\mathrm{Ba}}$, control experiments were carried out in which phorbol esters were applied after the addition of $100 \mu \mathrm{M} \mathrm{Cd}$ to the bath, to further rule out potential effects of phorbol esters on $I_{k}$. These control experiments revealed no effects of phorbol esters on $\mathrm{I}_{\mathrm{K}}(n=4$ cells). Another C-kinase activator, OAG, also enhanced $\mathrm{I}_{\mathrm{Ba}}$ in injected oocytes. The effect of $100 \mu \mathrm{M}$ OAG was more rapid in onset $(<1 \mathrm{~min})$ but was smaller $(26 \pm 3 \% ; n=$ 3).

In contrast to the effects of C-kinase activation by phorbol ester, $50 \mu \mathrm{M}$ forskolin, used to activate protein kinase $\mathrm{A}$, did not alter $I_{\mathrm{Ba}}$ even when cells were preincubated for $1 \mathrm{hr}$ in 10 mM theophylline to inhibit phosphodiesterases. However, forskolin did have an inhibitory effect on $\mathrm{I}_{\mathrm{K}}$. In the presence of $\mathrm{Cd}$, forskolin decreased $\mathrm{I}_{\mathrm{K}} 34 \pm 7 \%,(n=7)$. Attempts to modulate $I_{\mathrm{Ba}}$ by acetylcholine and isoproterenol yielded no change in $\mathrm{I}_{\mathrm{Ba}}$.

\section{Discussion}

A major finding of this study is the distinction, both in kinetic and pharmacological terms, between the Ba currents induced by heart mRNA (Dascal et al., 1986) and those induced by brain RNA (the present study). Heart RNA directs the synthesis of channels producing 2 components. The sustained component resembles the dihydropyridine-sensitive, A-kinase-modulated channels that underlie the slow inward current (the " $L$ " channels of Tsien and collaborators; see Nilius et al., 1985). The transient 


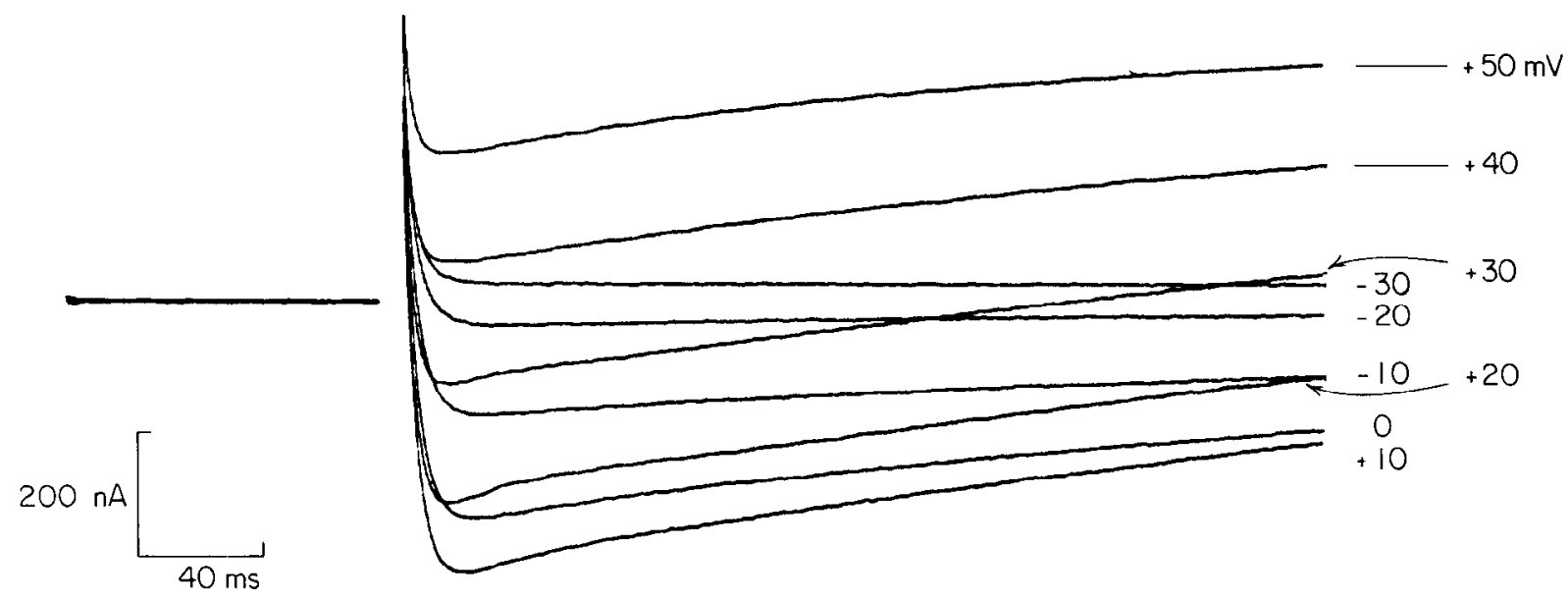

Figure 4. $\mathrm{I}_{\mathrm{Ba}}$ in $\mathrm{BaCl}_{2}$ saline. $\mathrm{I}_{\mathrm{Ba}}$ was elicited by depolarizing voltage steps from a holding potential of $-80 \mathrm{mV}$ to indicated voltages. Inward currents at voltages positive to $-20 \mathrm{mV}$ could not be carried by $\mathrm{Cl}$ as $\mathrm{E}_{\mathrm{Cl}}=-25 \mathrm{mV}$. Cd-insensitive currents were not subtracted in this example.

component is not well characterized, but may resemble the " $\mathrm{T}$ " channels (Bean, 1985; Nilius et al., 1985).

Although our preliminary studies suggested that a rapidly decaying (150-200 ms) transient component of Ba current occurs in Xenopus oocytes after injection of rat brain mRNA (Dascal et al., 1986), we now believe that the apparent rapid transient component resulted artifactually when the large $\mathrm{K}$ currents induced by brain RNA distorted the time course of the $B a$ current. In the present study, we obtained larger signals and better suppression of $\mathrm{K}$ currents; we detected only a single type of current which is, however, still partially transient (time constant of $\sim 650 \mathrm{~ms}$ ). We searched for additional components by examining the waveforms and current-voltage relationships as influenced by holding potential, by Cd blockade, by dihydropyridines, and by kinase activation. No additional components were detected, although single-channel data would be more decisive. For purposes of comparison, we will summarize the properties of this current (with $\mathrm{Ba}$ as the charge carrier): relatively slow inactivation, peak current at $+15 \mathrm{mV}$, half-maximal blockade by $\mathrm{Cd}$ at $<10 \mu \mathrm{M}$, insensitivity to the dihydropyridines, insensitivity to $\omega$-CgTX, insensitivity to forskolin, and enhancement by phorbol cstcrs.

Comparison with vertebrate CNS Ca channels. Other studies have examined dihydropyridine sensitivity in a variety of vertebrate $\mathrm{CNS}$ neurons. $\mathrm{Ca}$ action potentials and $\mathrm{I}_{\mathrm{Ca}}$ from Xenopus spinal cord, guinea pig olfactory cortex, and rat locus coeruleus neurons are resistant to the dihydropyridine "calcium antagonists" (Bixby and Spitzer, 1984; Williams et al., 1984; Kuan et al., 1985). Indirect examination of Ca-channel activity by measurement of neurotransmitter release also suggests the presence of dihydropyridine "calcium antagonist"-resistant $\mathrm{Ca}$ channels in cultured nigrostriatal neurons (Shalaby et al., 1984). In one case, however (hippocampal neurons), a maintained $\mathrm{I}_{\mathrm{C}}$ is sensitive to nimodopine (Brown et al., 1985).

In our study, it is possible that if a small amount of mRNA encoding dihydropyridine-sensitive Ca channels were present, we would not detect these channels above the background of the larger dihydropyridine-insensitive current. It will be of interest to examine currents induced by mRNA from specific brain regions and from rats of various ages. It is also possible that the channels expressed in oocytes lacked a subunit or the correct postranslational modifications necessary for dihydropyridine sensitivity. This latter possibility seems unlikely, given that heart mRNA injections induced dihydropyridine-sensitive $\mathrm{Ca}$ channels in oocytes.

All neurons presumably express the voltage-dependent $\mathrm{Ca}$ currents involved in transmitter release. Could such channels be responsible for our $\mathrm{I}_{\mathrm{Ba}}$ ? Presynaptic Ca channels have not been studied with voltage-clamp techniques in vertebrate tissues. Work on ${ }^{45} \mathrm{Ca}$ fluxes in synaptosomes, however, suggests that depolarization-activated $\mathrm{Ca}$ channels inactivate within 1 $\mathrm{sec}$, and that this inactivation has a substantial voltage-dependent component (Nachshen, 1985; Turner and Goldin, 1985a, b; Suszkiw et al., 1986). One would still expect to observe voltage-dependent inactivation with $\mathrm{Ba}$ as the charge carrier, and the time constant is similar to our observations. There are conflicting reports on Ca-channel blockade by dihydropyridines in synaptosomes (Nachshen and Blaustein, 1979; Turner and Gol-

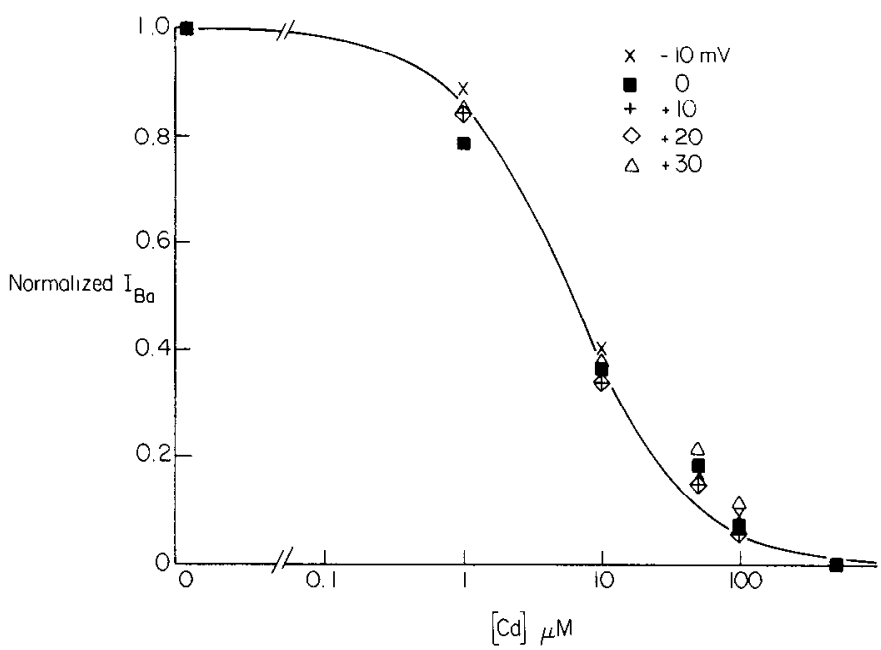

Figure 5. Cd dose-response curve. The degree of inhibition by $\mathrm{Cd}$ of peak $\mathrm{I}_{\mathrm{Ba}}$ was similar at the various voltages examined $(-10$ to $+30 \mathrm{mV})$. The response in the presence of $500 \mu \mathrm{M} \mathrm{Cd}$ was defined as complete blockade and used to subtract Cd-insensitive currents from total currents at all other concentrations of $\mathrm{Cd}$. The smooth curve represents theoretical single-site competitive inhibition, with a dissociation constant for Cd of $6 \mu \mathrm{M}$. 
$A$

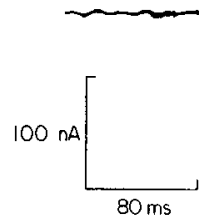

$80 \mathrm{~ms}$
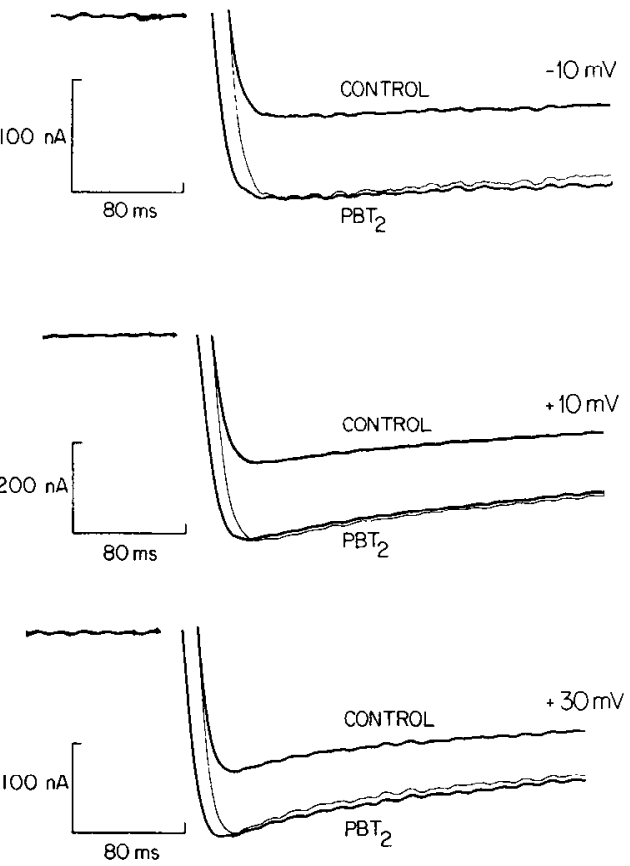

B

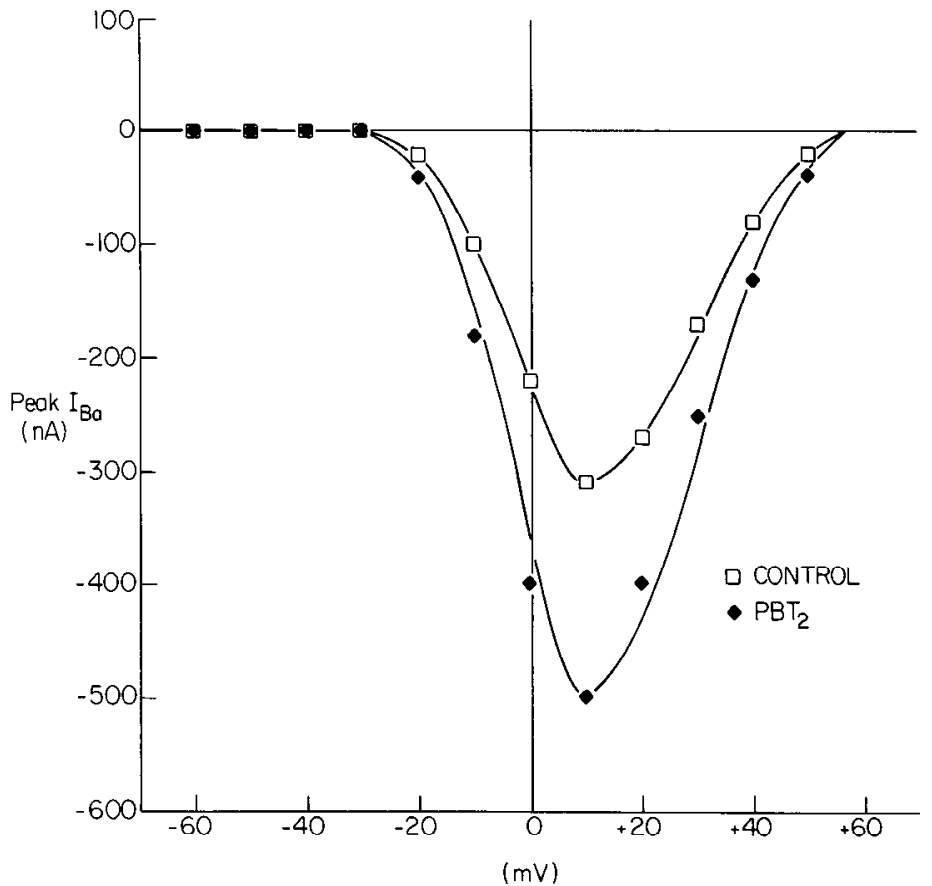

$(\mathrm{mV})$

Figure 6. Enhancement of $\mathrm{I}_{\mathrm{Ba}}$ by C-kinase activator $\mathrm{PBT}_{2}, A$, Depolarization from a holding potential of $-80 \mathrm{mV}$ to indicated voltages elicited $\mathrm{I}_{\mathrm{Ba}}$, which was enhanced $\sim 60 \%$ after $15 \mathrm{~min}$ in $100 \mathrm{nM} \mathrm{PBT}_{2}$. Thin trace is control current scaled up by factors between 1.5 and 1.8 to show that the kinetics of $\mathrm{I}_{\mathrm{Ba}}$ are unchanged after $\mathrm{PBT}_{2}, B$, Current-voltage relationship before and after $100 \mathrm{nM} \mathrm{PBT}_{2}$ for the same cell as in $A$. Smooth curve was fitted to open squares (control values) by eye. This curve was then scaled up $1.6 \times$ and superimposed on the post-PBT ${ }_{2}$ values $($ filled diamonds). The close fit of the scaled control curve and the post-PBT ${ }_{2}$ values suggests that the PBT $_{2}$ effect does not depend on voltage over the range tested. Cd-insensitive currents were subtracted.

din, 1985a, b; Suszkiw et al., 1986). Dihydropyridine-resistant ${ }^{45} \mathrm{Ca}$ uptake into a rat brain synaptosome preparation is partially inhibited by $\omega$-CgTX (Reynolds et al., 1986). The failure of $\omega$-CgTX to block Ca channels in our system thus remains to be explained. Overall, the available data are consistent with the hypothesis that the channels observed in the present study include the presynaptic voltage-dependent $\mathrm{Ca}$ channels involved in transmitter release.

Modulation. Although Ba currents directed by heart mRNA are increased by $\beta$-agonists and by forskolin (both presumably acting via CAMP-activated protein kinase), the present experiments reveal no such effect on Ba currents directed by brain mRNA. Forskolin nonetheless seems to be activating a kinase, and that kinase does seem able to influence membrane proteins: we find that forskolin diminishes the $\mathrm{K}$ currents directed by brain mRNA, as well as affecting the heart mRNA-encoded Ca channels, as indicated above.

Phorbol esters, on the other hand, enhanced the brain mRNAencoded $\mathrm{Ca}$ channels. The action was presumably mediated via C-kinase, since the enhancement was also observed with the C-kinase activator OAG, but not with the inactive phorbol ester analog, 4- $\alpha$-phorbol. Some mammalian Ca currents are decreased by C-kinase activation (Baraban et al., 1985; Werz and MacDonald, 1985; Rane and Dunlap, 1986), but increases have been observed with molluscan neurosecretory and nerve cells (De Riemer et al., 1985; Paupardin-Tritsch et al., 1985) and traced to the appearance of a new population of Ca-channel openings with a larger conductance (Strong et al., 1986). Is the increase we observed due to phosphorylation of the channels?
It is impossible to answer this question decisively at present, but the enhancement was much smaller in Na-free Ringer's solution. One must therefore consider C-kinase activation of $\mathrm{Na}$-proton and $\mathrm{Na}-\mathrm{Ca}$ exchange systems (Swann and Whitaker, 1985); increased intracellular pH (Kurachi, 1982) or pCa (Tillotson, 1979) could increase currents through $\mathrm{Ca}$ channels. We believe that future experiments with cell-free patches will give more decisive answers to questions about the mechanism of Cachannel modulation in oocytes injected with brain mRNA.

\section{References}

Armstrong, C. M., and D. R. Matteson (1985) Two distinct populations of calcium channels in a clonal line of pituitary cells. Science 227: 65-67.

Baraban, J. M., S. H. Snyder, and B. E. Alger (1985) Protein kinase $\mathrm{C}$ regulates ionic conductance in hippocampal pyramidal neurons: Electrophysiological effects of phorbol esters. Proc. Natl. Acad. Sci. USA 82: 2538-2542.

Barish, M. E. (1983) A transient calcium-dependent chloride current in the immature Xenopus oocyte. J. Physiol. (Lond.) 342: 309-325.

Baud, C., R. Kado, and K. Marcher (1982) Sodium channels induced by depolarization of the Xenopus laevis oocyte. Proc. Natl. Acad. Sci. USA 79: 3188-3192.

Bean, B. P. (1984) Nitrendipine block of cardiac calcium channels: High affinity binding to the inactivated state. Proc. Natl. Acad. Sci. USA 81: 6388-6392.

Bean, B. P. (1985) Two kinds of calcium channels in canine atrial cells. Differences in kinetics, selectivity, and pharmacology. J. Gen. Physiol. 86: 1-30.

Bixby, J. L., and N. C. Spitzer (1984) Early differentiation of vertebrate spinal neurons in the absence of voltage dependent $\mathrm{Ca}$ and $\mathrm{Na}$ influx. Dev. Biol. 106: 89-96.

Brown, D. A., A. Constanti, R. J. Docherty, M. Galvan, B. Gahwiler, 
and J. V. C. Halliwell (1985) Pharmacology of calcium currents in mammalian central neurones. Proceedings of the Ninth IUPHAR Symposium, Vol. 2, pp. 343-348.

Carbone, E., and H. D. Lux (1984a) A low voltage-activated calcium conductance in embryonic chick sensory neurons. Biophys. J. 46:413418.

Carbone, E., and H. D. Lux (1984b) A low voltage-activated, fully inactivating $\mathrm{Ca}$ channel in vertebrate sensory neurons. Nature 310 501-503.

Chirgwin, J. M., A. E. Przybyla, R. J. MacDonald, and W. J. Rutter (1979) Isolation of biologically active ribonucleic acid from sources enriched in ribonuclease. Biochemistry 18: 5294-5299.

Contreras, R., H. Cheroutre, and W. Fiers (1981) A simple apparatus for injection of nanoliter quantities into Xenopus laevis oocytes. Anal. Biochem. 113: 185-187.

Dascal, N. (1987) Use of the Xenopus oocyte system to study ion channels. CRC Crit. Rev. Biochem. (in press).

Dascal, N., T. P. Snutch, H. Lubbert, N. Davidson, and H. A. Lester (1986) Expression and modulation of voltage gated-calcium channels after RNA injection in Xenopus oocytes. Science 231: 1147-1150.

De Riemer, S. A., J. A. Strong, K. A. Albert, P. Greengard, and L. K. Kaczmarek (1985) Enhancement of calcium current in Aplysia neurones by phorbol ester and protein kinase $C$. Nature 313: 313-316.

Dierks, P., A. van Ooyen, N. Mantei, and C. Weissmann (1981) DNA sequences preceding the rabbit b-globin gene are required for formation in mouse L-cells of b-globin RNA with the correct $5^{\prime}$ terminus. Proc. Natl. Acad. Sci. USA 78: 1411-1415.

Gundersen, C. B., R. Miledi, and I. Parker (1983) Serotonin receptors induced by exogenous messenger RNA in Xenopus oocytes. Proc. R. Soc. Lond. [Biol.] 219: 103-109.

Houamed, K. M., G. Bilbe, T. G. Smart, A. Constanti, D. A. Brown E. A. Barnard, and B. M. Richards (1984) Expression of functional GABA, glycine and glutamate receptors in Xenopus oncytes injected with rat brain mRNA. Nature 310:318-321.

Kuan, Y. F., C. N. Scholfield, and L. C. Steel (1985) Effect of Ca antagonists on axonal $\mathrm{Ba} / \mathrm{Ca}$ spikes in slices of guinea-pig brain. $\mathrm{J}$. Physiol. (Lond.) 362.

Kurachi, Y. (1982) The effects of intracellular protons on the electrical activity of single ventricular cells. Pfluegers Arch. 394: 264-270.

Maniatis, T., E. F. Fritsch, and J. Sambrook (1982) Molecular Cloning, Cold Spring Harbor Laboratory, Cold Spring Harbor, NY.

Miledi, R. (1982) A calcium-dependent transient outward current in Xenopus laevis oocytes. Proc. R. Soc. Lond. [Biol.] 215: 491-497.

Nachshen, D. A. (1985) The early time course of potassium stimulated calcium uptake in presynaptic nerve terminals isolated from the rat brain. J. Physiol. (Lond.) 361: 251-268.

Nachshen, D. A., and M. P. Blaustein (1979) The effects of some organic "calcium antagonists" on calcium influx in presynaptic nerve terminals. Mol. Pharmacol. 16: 579-586.

Nilius, B., P. Hess, J. B. Lansman, and R. W. Tsien (1985) A novel type of cardiac calcium channel in ventricular cells. Nature 316:443446.

Nowycky, M. C., A. P. Fox, and R. W. Tsien (1985) Long-opening mode of gating of neuronal calcium channels and its promotion by the dihydropyridine calcium agonist Bay K 8644. Proc. Natl. Acad. Sci. USA 82: 2178-2182.

Paupardin-Tritsch, D., C. Hammond, and H. M. Gerschenfeld (1985) A serotonin-induced increase in calcium current in identified molluscan neurons mimicked by cGMP but not by cAMP. Soc. Neurosci Abstr. 11: 466 .

Rane, S. G., and K. Dunlap (1986) Kinase C activator, 1,2-oleoylacetylglycerol attenuates voltage-dependent calcium current in sensory neurons. Proc. Natl. Acad. Sci. USA 83: 184-188.

Reynolds, I. J., J. A. Wagner, B. M. Olivera, R. J. Miller, and S. H. Snyder (1986) Omega-conotoxin blocks dihydropyridine-insensitive calcium uptake into synaptosomes. Soc. Neurosci. Abstr. 12: 176.

Sanguinetti, M. C., and R. S. Kass (1984) Voltage-dependent block of calcium channel current in the calf cardiac Purkinje fiber by dihydropyridine calcium channel antagonists. Circ. Res. 55: 336-348.

Shalaby, I. A., S. Kongsamut, S. B. Freedman, and R. J. Miller (1984) The effects of dihydropyridines in ncurotransmitter release from cultured neuronal cells. Life Sci. 35: 1289-1295.

Soreq, H. (1985) The biosynthesis of biologically active proteins in mRNA-microinjected Xenopus oocytes. CRC Crit. Rev. Biochem. I8. 199-238.

Strong, J. A., A. P. Fox, R. W. Tsien, and L. K. Kaczmarek (1986) Phorbol ester promotes a large conductance $\mathrm{Ca}$ channel in Aplysia bag cell neurones. Biophys. J. 49:430a.

Suszkiw, J. B., M. E. O'Leary, M. M. Murawsky, and T. Wang (1986) Presynaptic calcium channels in rat cortical synaptosomes: Fast-kinetics of phasic calcium influx, channel inactivation, and relationship to nitrendipine receptors. J. Neurosci. 6: 1349-1357.

Swann, K., and M. Whitaker (1985) Stimulation of the $\mathrm{Na} / \mathrm{H}$ exchanger of sea urchin eggs by phorbol ester. Nature 314:274-277.

Tillotson, D. (1979) Inactivation of Ca conductance dependent on entry of $\mathrm{Ca}$ ions in molluscan neurons. Proc. Nat. Acad. Sci. USA 76: $1497-1500$

Turner, T. J., and S. M. Goldin (1985a) Calcium channels in rat brain synaptosomes: Identification and pharmacological characterization. J. Neurosci. 5: 841-849.

Turner, T. J., and S. M. Goldin (1985b) Effects of dihydropyridine agonists and antagonists in $\mathrm{Ca}^{2+}$ uptake and neurotransmitter release by rat brain synaptosomes. Soc. Neurosci. Abstr. 11: 579.

Werz, M. A., and R. L. MacDonald (1985) Phorbol esters: Opposing effects on calcium dependent action potentials of dorsal root ganglion neurons. Soc. Neurosci. Abstr. 11:747.

Williams, J. T., R. A. North, S. A. Shefner, S. Nishi, and T. M. Egan (1984) Membrane properties of rat locus coeruleus neurones. Neuroscience $13: 137-156$. 